\title{
Schopenhauer, Nietzsche e a crítica ao formalismo da moral kantiana
}

\author{
Renato Nunes Bittencourt \\ Doutor em Filosofia pelo PPGF - UFRJ \\ Professor do Curso de Comunicação Social da Faculdade CCAA \\ Membro do Grupo de Pesquisa Spinoza \& Nietzsche
}

RESUMO: Neste artigo apresentamos as convergências entre Schopenhauer e Nietzsche na crítica ao formalismo da moral kantiana, sustentada pelo primado do dever, postulado pretensamente racional que exige o cumprimento da ação moral do indivíduo de maneira objetiva, sem manifestação de quaisquer inclinações pessoais. Schopenhauer e Nietzsche, apesar de apresentarem pontos divergentes acerca do valor existencial da compaixão, apresentam argumentos éticos que se chocam violentamente com a doutrina kantiana da moral, uma ilusão deletéria para a condução prática da vida humana.

PALAVRAS-CHAVE: Dever; Formalismo; Ética.

\begin{abstract}
In this article we present the convergences between Schopenhauer and Nietzsche in the critical one to the formalism of the Kantian moral, supported for the primate of the duty, supposedly rational postulate who demands the fulfillment of the moral action of the individual in objective way, without manifestation of any personal inclinations. Schopenhauer and Nietzsche, although to present divergent points concerning the existencial value of the compassion, present ethical arguments that if shock violently with the Kantian doctrine of the moral, a deleterious illusion for the practical conduction of the life human being.
\end{abstract}

KEYWORDS: Duty; Formalism; Ethic.

Oh dever! Sublime e grande nome, que não compreendes em ti nada benquisto que comporte adulação mas reivindicas submissão, contudo tampouco ameaças com algo que para mover a vontade provocasse no ânimo aversão natural e o atemorizasse, porém simplesmente propões uma lei que por si encontra acesso ao ânimo e que, todavia, mesmo a contragosto granjeia para si veneração (embora nem sempre observância), ante a qual todas as inclinações emudecem, mesmo que secretamente se oponham a ela: qual é a origem digna de ti e onde se encontra a raiz de tua nobre linhagem, que altivamente rejeita todo o parentesco com inclinações e de cuja raiz descender constitui a condição indispensável daquele valor que unicamente os homens podem dar a si mesmos? (KANT, I. Crítica da Razão Prática, Ak 154, p. 140).

\section{Introdução}

A filosofia de Schopenhauer influenciou profundamente a elaboração das teorias estéticas e educacionais de Nietzsche, em especial nas suas obras compreendidas entre 
1871-1876 ${ }^{1}$. A partir de Humano, demasiado humano, Nietzsche salientará um distanciamento axiológico em relação ao pensamento schopenhaueriano, criticando sua metafísica do belo e sua acepção de gênio; além disso, haverá a recusa de sua teoria ética, que veremos a seguir no decorrer deste artigo. Entretanto, apesar de apontar essa ruptura intelectual com a obra de seu "mestre" - denominação respeitosa apresentada no $\S 5$ do Prólogo de sua Genealogia da Moral - Nietzsche demonstraria ainda manter algumas convergências com a filosofia de Schopenhauer, acima de tudo no projeto de refutação do conceito de dever postulado por Kant em sua racionalidade prática. Nessas condições, Schopenhauer e Nietzsche se caracterizam, no plano da valoração ética, como críticos radicais do formalismo da moral kantiana: Schopenhauer considera-a um abstracionismo espúrio que nega o sentido genuíno da ética, calcada na compaixão; Nietzsche, por sua vez, considera o rigorismo do dever kantiano um dispositivo negador da própria espontaneidade e do poder criativo da vida.

Conforme destacado nas linhas acima, Nietzsche direciona fortes críticas ao primado ético da compaixão em Schopenhauer, imputando-a como expressão da decadência vital, da própria fraqueza fisiológica do indivíduo ${ }^{2}$. A “ética" de Nietzsche pressupõe a capacidade de afirmação da dor e da tragicidade da vida mesmo nas circunstâncias mais terríveis para a manutenção da própria individualidade. ${ }^{3}$ Entretanto, apesar da divergência axiológica entre essas duas perspectivas éticas, a grande associação filosófica se manifesta na recusa ao primado do dever kantiano, artificialismo vazio que em nada contribui para a compreensão da especificidade da ação humana e para uma tomada de posição existencial mais potente, afirmadora de todas as circunstâncias.

\footnotetext{
${ }^{1}$ Destacamos aqui $O$ nascimento da Tragédia, no qual Nietzsche reveste as suas análises estéticas sobre o advento da Tragédia Ática através de conceitos schopenhauerianos, assim como a Terceira Consideração Intempestiva, "Schopenhauer Educador", na qual elege o autor de O Mundo como Vontade e como Representação o modelo do autêntico filósofo, exemplo de vida dedicada ao pensamento sem se importar com as flutuações das opiniões das massas e sem depender da adequação ao status quo.

2 NIETZSCHE, F. Genealogia da Moral, "Prólogo", § 5; O Anticristo, § 7, p. 14.

${ }^{3}$ Para ilustração dessa colocação, podemos nos remeter a Crepúsculo dos Ídolos, "Máximas e Flechas", § 8, p. 10: "Da Escola de Guerra da vida. - O que não me mata me fortalece", assim como a Ecce Homo, "Por que sou tão inteligente", $\S 10$, p. 51: "Minha fórmula para a grandeza do homem é amor fati: nada querer diferente, seja para trás, seja para a frente, seja em toda a eternidade. Não suportar apenas o necessário, menos ainda ocultá-lo - todo idealismo é mendacidade ante o necessário - mas amá-lo...”
} 


\section{Schopenhauer contra o formalismo da moral kantiana}

Para Kant, a legitimidade da ação moral se fundamenta somente quando é empreendida a partir do cumprimento rigoroso ao mandamento racional do dever, assim descrito: "O dever é a necessidade de uma ação por respeito à lei”. ${ }^{4} \mathrm{O}$ cumprimento do dever se dá por sua instituição nas faculdades racionais do ser humano como um imperativo categórico: "Age apenas segundo uma máxima tal que possas ao mesmo tempo querer que ela se torne lei universal"s.

Por conseguinte, conforme o encadeamento pautado no cumprimento do dever, a condição para que uma ação venha a ser legitimada moralmente residiria na existência do desinteresse do indivíduo que estabelece a ação virtuosa em relação ao receptor, impossibilitando, consequentemente, que o praticante de tais atos de benevolência venha a nutrir alguma inclinação perante o ser sofredor. Ações pautadas a partir do desenvolvimento do sentimento de afeição do doador para com o sofredor são radicalmente desconsideradas no sistema moral formulado por Kant, pois tais ações seriam realizadas por uma motivação dos impulsos dos sentimentos, não da rígida e refletida aplicação da razão prática pura. Tal como argumenta Kant,

Ser caritativo quando se pode sê-lo é um dever, e há além disso muitas almas de disposição tão compassiva que, mesmo sem nenhum outro motivo de vaidade ou interesse, acham íntimo prazer em espalhar alegria à sua volta e se podem alegrar com o contentamento dos outros, enquanto este é obra sua. Eu afirmo porém que neste caso uma tal ação, por conforme ao dever, por amável que ela seja, não tem contudo nenhum verdadeiro valor moral, mas vai emparelhar com outras inclinações, por exemplo o amor das honras que, quando por feliz acaso toma aquilo que efetivamente é de interesse geral e conforme ao dever, é conseqüentemente honroso e merece louvor e estímulo, mas não estima; pois à sua máxima falta o conteúdo moral que manda que tais ações se pratiquem não por inclinação, mas por dever ${ }^{6}$.

Nessas condições, de acordo com o postulado kantiano, tal circunstância retiraria qualquer valor moral das ações realizadas por um sujeito que, por exemplo, viesse a auxiliar um homem carente através do despertar do afeto de piedade ou comiseração para

\footnotetext{
${ }^{4}$ KANT, I. Fundamentação da Metafísica dos Costumes, Primeira Seção, Ak 14, p. 31.

${ }^{5}$ KANT, I. Fundamentação da Metafísica dos Costumes, Segunda Seção, Ak 52, p. 59.

${ }^{6}$ KANT, I. Fundamentação da Metafísica dos Costumes, Primeira Seção, Ak 10, p. 28.
} 
com o seu padecimento evidenciado empiricamente por esse indivíduo. Kant prossegue na sua desconsideração pelo valor moral da ação caritativa ao afirmar que

Mesmo uma ação que é conforme ao dever (por exemplo, à caridade) pode, em verdade, facilitar muito a eficácia das máximas morais mas não pode produzir nenhuma delas. Pois nesta, se a ação não deve conter simplesmente legalidade mas moralidade, tudo tem de estar voltado para a representação da lei como fundamento determinante. A inclinação, quer seja de boa índole ou não, é cega e servil, e a razão, onde se tratar da moralidade, não tem que simplesmente representar a menoridade da mesma, mas, sem a tomar em consideração, tem de cuidar totalmente sozinha como razão prática pura de seu próprio interesse. Até este sentimento de compaixão e de meiga participação, se precede a reflexão sobre o que é dever e torna-se fundamento determinante, é penoso mesmo a pessoas bem-pensantes, confunde suas refletidas máximas e provoca o desejo de livrar-se dele e de submeter-se unicamente à razão legislativa ${ }^{7}$.

Não sem justiça e probidade intelectual Schopenhauer associa a ação moral guiada pela mera adequação ao princípio formalista de dever ao Decálogo Mosaico ${ }^{8}$. A redação da ética, em uma forma imperativa, como doutrina dos deveres, e o julgar o valor ou o não-valor das ações humanas como cumprimento ou violação de deveres provêm, junto com o dever, inegavelmente só da moral teológica e, logo, do código sacerdotal que impõe ao individual a prescrição de regras fundamentadas em parâmetros transcendentes ao mundo concreto. Esclarecendo essa questão, Vilmar Debona argumenta que

A ética schopenhaueriana não se baseia no dever, ela não prescreve regras, mas procura explicitar o que acontece e perceber como os homens de fato agem. Toda ação deve ter algum motivo e é principalmente para as motivações que se deve olhar (DEBONA, V. Schopenhauer e as formas da razão, p. 90).

Agir pelo cumprimento absoluto do dever é estabelecer um automatismo na consciência ética do ser humano, tornando-o frio existencialmente e indiferente em relação ao ser do outro. O conceito de dever, ou seja, a forma imperativa da ética somente pode ser válida na moral teológica, perdendo assim todo sentido e significação fora dela ${ }^{9}$. Conforme sentencia criticamente Schopenhauer sobre a inocuidade do formalismo kantiano:

\footnotetext{
7 KANT, I. Crítica da Razão Prática, Ak 212-213, p. 191-192.

8 SCHOPENHAUER, A. M, § 4, p. 25.

9 SCHOPENHAUER, A. M, § 13, p. 119.
} 
O valor do caráter só se institui quando alguém sem simpatia no coração, frio e indiferente ao sofrimento de outrem, realiza boas ações não nascidas, na verdade, da solidariedade humana, mas apenas por causa do enfadonho dever ${ }^{10}$.

Ao contrário de Kant, que preconizava como ação moral válida apenas aquele que fosse desenvolvida a partir de postulados objetivos externos ao da esfera empírica e suas peculiaridades, originada pela compreensão o formalismo do dever nas faculdades racionais do ser humano, Schopenhauer formula precisamente o estabelecimento de uma prática moral fundamentada na experiência da vida ${ }^{11}$. Conforme argumenta Christopher Janaway, a moral prática - a tomada de decisões e o juízo - se volta para o comportamento real de seres humanos individuais que ocupam o domínio empírico. Esse deve ser igualmente, o foco da discussão teórica que Schopenhauer chama de "moral"12. Maria Lúcia Cacciola, por sua vez, afirma que

O fundamento da ética desloca-se pois da razão e de seus imperativos para o sentimento, e à moral do dever contrapõe-se uma moral do ser, a moral da compaixão ${ }^{13}$.

Para Schopenhauer, a ausência de toda motivação egoísta é o critério de uma ação dotada de valor moral ${ }^{14}$. Com efeito, quem se encontra destituído do egoísmo nas suas disposições práticas manifesta a abertura existencial para a realização da genuína ação moral fundamentada na compaixão. É a ilusão fenomênica gerada pelo princípio de individuação, isto é, a separação espaço-temporal entre os inúmeros seres vivos, que motiva o sentimento e a percepção de distanciamento do "sujeito" em relação ao mundo circundante $^{15}$. A compaixão rompe com o paradigma da separação entre o "eu" e o "tu", pólos que, considerados para além de todas as evidências aparentes, são o mesmo ser. Em decorrência de tal perspectiva axiológica, Schopenhauer se encontrará em condições de considerar que as ações morais autênticas ocorrem quando se manifesta a interação

\footnotetext{
${ }^{10}$ SCHOPENHAUER, A. M, $\S 6$, p. 40.

${ }^{11}$ SCHOPENHAUER, A. M, § 14, p. 120.

12 JANAWAY, C. Schopenhauer, p. 111.

${ }^{13}$ CACCIOLA, M. L. Schopenhauer e a questão do dogmatismo, p.156.

${ }^{14}$ SCHOPENHAUER, A. M, § 15, p. 131.

${ }^{15}$ SCHOPENHAUER, MVR, I, § 23, p.171.
} 
imediata entre o doador e o padecente mediante a experiência de associação ontológica proporcionada pela compaixão ${ }^{16}$.

Dessa maneira, a ética schopenhaueriana se desvincula de qualquer ligação com a perspectiva kantiana, incapaz de explicar adequadamente a fundamentação metafísica da ação moral humana a partir da pura racionalidade. A "demonização" dos afetos feita por Kant demonstra de modo nítido a sua incapacidade de distinguir os afetos humanos segundo as suas influencias práticas. Um gesto de pretensa caridade realizado em vista da conquista de uma benesse divina ou social é certamente hipócrita, mas isso não invalida a pertinência de uma ação moral que seja guiada por afetos verdadeiramente caritativos, amorosos. Comentando essa questão schopenhaueriana, Renato César Cardoso afirma que

O que caracteriza o ato moral, virtuoso, ensina Schopenhauer, é exatamente o contrário do que propunha Kant, é o amor, a compaixão, o compadecimento (...). Não é na aridez e na frieza da racionalidade que se encontra o fundamento da moralidade, mas sim, ensina Schopenhauer, no tomar para si, como seu, o sofrimento do outro ${ }^{17}$.

Nesses termos, a racionalidade abstrata é incapaz de expressar o âmago metafísico que envolve todos os seres vivos, assim como os princípios fundamentais daquela que seria a verdadeira ação moral, que encontra sua puríssima expressão no fenômeno místico da compaixão, tal como explicitada por Schopenhauer:

Toda boa ação totalmente pura, toda ajuda verdadeiramente desinteressada que, como tal, tem exclusivamente por motivo a necessidade de outrem, é, quando pesquisada até o seu último fundamento, uma ação misteriosa, uma mística prática, contanto que surja por fim do mesmo conhecimento que constitui a essência de toda mística propriamente dita e não possa ser explicável com verdade de nenhuma outra maneira ${ }^{18}$.

Para despertar a compaixão comprovada como a única fonte de ações altruístas e por isso como a verdadeira base da moralidade, não é preciso nenhum conhecimento

${ }^{16}$ Cabe destacar que Ernst TUGENDHAT, no texto "A Ética da Compaixão: animais, crianças e vida pré-natal” (compilado em seu livro Lições sobre Ética), apresenta inestimáveis contribuições filosóficas para a comparação entre as perspectivas de Kant e de Schopenhauer acerca das bases fundamentais daquela que seria a genuína ação moral, em especial nas p.191-192.

${ }^{17}$ CARDOSO, R. C. A ideia de justiça em Schopenhauer, p. 101.

${ }^{18}$ SCHOPENHAUER, A, M, § 22, p. 221. 
abstrato, mas apenas o intuitivo, a mera apreensão do caso concreto, no qual a compaixão logo se revela sem maiores mediações do pensamento ${ }^{19}$.

A legitimidade da ação moral origina-se da identificação do agente para com o outro, da supressão do princípio de individuação aos olhos do indivíduo que age em sua relação imediata com o mundo. Schopenhauer é categórico ao considerar que uma ação somente possui valor moral quando ela surge da compaixão, e toda ação que se produz por qualquer outro motivo não tem nenhum valor ${ }^{20}$. A compaixão é o sentimento de integração interpessoal e a experiência de unidade ontológica que associa intimamente o "eu" e o “outro". Nesse processo transfigurador da própria identidade, o homem compassivo se afeta imediatamente pelo fato de ver concretamente a manifestação brutal da dor alheia, o mal que aflige outrem, pois a compaixão se caracteriza por levar o homem ético a vivenciar no seu íntimo a realidade interior do outro. Inclusive, cabe ressaltar que mesmo a participação do bem-estar do outro também se coaduna com a esfera da compaixão, pois se esta visa promover a interação do "eu” com o "outro", qualquer disposição afirmativa vivenciada pelo "tu” pode ser absorvida no fenômeno da compaixão. De acordo com Schopenhauer,

(...) como é de algum modo possível que o bem-estar ou o mal-estar de um outro mova imediatamente a minha vontade, isto é, como se fosse o meu próprio, tornando-se portanto diretamente o meu motivo, e isto até mesmo num tal grau, que eu menospreze por ele, mais ou menos, o meu bem-estar, do contrário, a única fonte dos meus motivos? Manifestamente, só por meio do fato de que o outro se torne de tal modo o fim último de minha vontade como eu próprio o sou. Através, portanto, do fato de que quero imediatamente seu bem e de que não quero seu mal, tão diretamente como se fosse o meu. Isto, porém, pressupõe necessariamente que eu sofra com o seu mal-estar, sinta seu mal como se fora o meu e, por isso, queira seu bem como se fora o meu próprio. Isto exige porém que eu me identifique com ele, quer dizer, que aquela diferença total entre mim e o outro, sobre a qual repousa justamente meu egoísmo, seja suprimida pelo menos num certo grau $^{21}$.

Por conseguinte, percebemos um distanciamento axiológico radical em relação ao projeto kantiano de estabelecer uma razão prática sustentada por condições transcendentais.

\footnotetext{
${ }^{19}$ SCHOPENHAUER, A. M, § 19, p. 184.

${ }^{20}$ SCHOPENHAUER, A. M, $\S 16$, p. 136.

${ }^{21}$ SCHOPENHAUER, A. M, § 16, p. 135-136.
} 
Conforme esclarece Vilmar Debona acerca do polêmico contraponto que Schopenhauer estabelece em relação ao formalismo kantiano,

A questão fundamental é a de que, para Schopenhauer, a razão não chega a ser tão poderosa a ponto de dar origem e de fundamentar a moralidade. O imperativo categórico seria a própria lei que derivaria de tal capacidade e que teria por forma a legalidade. E é justamente por isso, em sua aversão ao formalismo da moral kantiana que o filósofo objeta um fundamento da moral meramente intelectual. Tal fundamento acarretaria carência de realidade e de efetividade ${ }^{22}$.

Na compreensão schopenhaueriana do estabelecimento metafísico da moralidade, suprime-se qualquer ideário teórico estabelecido através de um formalismo conceitual revestido por uma nuance imperativa que em nada contribuiriam para a realização da ação virtuosa; a teorização racional da ética, por si só, já representa uma negação da ação prática, pois esta nasce de um impulso de compreensão rigorosamente inefável da univocidade da vida. A norma moral e, geralmente, o conhecimento abstrato não pode promover a verdadeira virtude, assim como é impossível que um tratado de estética favoreça o surgimento de um indivíduo dotado de habilidades geniais.

\section{Nietzsche e a crítica ao formalismo do Dever}

Na obra de Nietzsche encontramos exemplos ilustrativos de sua rejeição ao primado formalista da moral kantiana em obras cronologicamente distantes como Assim falava Zaratustra e $O$ Anticristo, circunstância que evidencia uma perspectiva constante de incompatibilidade com a valoração kantiana. Um dos critérios fundamentais para o delineamento das críticas nietzschianas se sustenta pelo viés da noção de tonicidade da vida: toda valoração que não compreenda as especificidades intrínsecas da vida e que não favoreçam a sua afirmação imanente são discursos insidiosos, decadentes, plenamente prejudiciais para a existência humana. Por conseguinte, Kant, ao postular uma pretensa ética fundamentada aprioristicamente, em verdade retiraria qualquer significação da mesma, tornando-a, simbolicamente falando, algo como um edifício externamente

22 DEBONA, V. Schopenhauer e as formas da razão, p. 51. 
belíssimo, porém inabitável. O primado moral do dever em Kant é, conforme o enfoque nietzschiano, um sintoma de esterilidade criadora. Encontramos na Primeira Parte de Assim falava Zaratustra, no discurso "Das Três Metamorfoses", veladas críticas ao formalismo moral kantiano, revestidas com um belo aparato simbólico no qual Nietzsche apresenta o doloroso processo do espírito livre no ato de criação dos valores afirmativos da existência, suprimindo assim o peso da tradição, limitadora do potencial criativo dos indivíduos de exceção:

Qual é o grande dragão, a quem o espírito já não gosta de chamar seu senhor e seu deus? "Tu deves", chama-se o grande dragão. Mas o espírito do leão diz: "Eu quero". "Tu deves" está-lhe atravessado no caminho, faiscante como ouro, um animal coberto de escamas, e em cada escama brilha em letras douradas: "Tu deves!" (...) Para criar liberdade para si e dizer um sagrado "Não" mesmo ao dever, para tanto, meus irmãos, é necessário o leão $0^{23}$.

A partir de um exercício hermenêutico, podemos afirmar que a figura do leão representa a capacidade de contraposição ao peso dos valores morais criados pelo próprio homem, mas que foram hipostasiados por ele próprio em um processo de esquecimento do seu ato criador negativo, para uma dimensão pretensamente objetiva da ação moral, o imperativo categórico e sua sufocante premissa do dever. O leão, portanto, encontra-se na necessidade de reagir violentamente contra a decadência vital própria dos discursos normativos incapazes de compreenderem as particularidades da imanência da existência, exigindo do ser humano disposições morais irrealizáveis para que assim possa melhor subjugá-lo, mediante a imposição do sentimento de culpa em seu íntimo. Com efeito, o postulado do dever kantiano é uma versão mascarada do discurso ascético eclesiástico, travestido com os ornamentos retóricos da "filosofia crítica". Sendo impossível ao homem obter a santidade absoluta na vida física, e tal santidade é condição indispensável para a salvação, somente uma intervenção extrínseca ao mundo da imanência poderia elevar o homem sobre as inclinações sensíveis. Eis assim a necessidade da crença na graça divina. Nesse contexto, a doutrina cristã da redenção é mais coerente internamente do que a teoria do dever em Kant.

${ }^{23}$ NIETZSCHE, F. Assim falava Zaratustra, I, "Das Três Metamorfoses”, p. 29; p. 30. 
Por esse motivo Nietzsche aponta Kant como um "cristão insidioso"24. Todo o projeto de criação de uma filosofia livre dos preconceitos metafísico-teológicos se esvaiu através da fundamentação teleológica da razão prática: a fraqueza do projeto moral de Kant decorre do postulado da imortalidade da $\operatorname{alma}^{25}$ e da existência de Deus ${ }^{26}$ como garantias ao ser humano de que uma vida direcionada pelo cumprimento estrito do dever e ao aprimoramento moral a partir do estabelecimento da prática virtuosa desinteressada, por uma necessidade da própria razão, deveria se prolongar numa realidade supra-sensível, intrinsecamente livre das inclinações, a fim de que ela obtivesse o pleno aperfeiçoamento nessa dimensão inteligível.

Esse projeto kantiano não combina com o propósito nietzschiano pelo fato de que reintroduzir Deus no plano do fundamento da lei moral equivaleria a liquidar literalmente a imediatez e autonomia da razão prática, transferindo a sua raiz de um suporte intrínseco e essencialmente imanente ao homem para uma esfera transcendente ${ }^{27}$. Ora, isso significa que o sistema moral de Kant, contraditório em relação à própria vida pelo fato de não se sustentar em uma perspectiva imanente, depende de uma legitimidade metafísica para que ela se apresente como viável ao juízo avaliador do agente moral. Vejamos mais algumas colocações de Nietzsche:

Ainda uma palavra contra Kant como moralista. Uma virtude tem de ser nossa invenção, nossa defesa e necessidade personalíssima: em qualquer outro sentido é apenas um perigo. $O$ que não é condição de nossa vida a prejudica: virtude oriunda apenas de um sentimento de respeito ao conceito de "virtude", como queria Kant, é prejudicial. A"virtude", o "dever", o "bom em si", o bom com o caráter de impessoalidade e validade geral - fantasias nas quais se exprime o declínio, o esgotamento final da vida, o chinesismo königsberguiano. As mais profundas leis da conservação e do crescimento exigem o oposto: que cada qual invente sua virtude, seu imperativo categórico. Um povo perece, quando confunde seu dever com o conceito de dever em geral. Nada arruína mais profundamente, mais intimamente do que todo dever "impessoal", todo sacrifício ante o Moloch da abstração. - Que não se tenha percebido o imperativo categórico de Kant como perigoso para a vida!... Apenas o

\footnotetext{
${ }^{24}$ NIETZSCHE, F. Crepúsculo dos Ídolos, ““A razão’ na filosofia”, §6, p. 29.

${ }^{25}$ KANT, I. Crítica da Razão Prática, "Dialética da Razão Pura", $2{ }^{\circ}$ Capítulo, IV - "A imortalidade da alma como um postulado da razão prática".

${ }^{26}$ KANT, I. Crítica da Razão Prática, "Dialética da Razão Pura", $2^{\circ}$ Capítulo, V - "A existência de Deus como um postulado da razão prática pura".

${ }^{27}$ Cf. SOROMENHO-MARQUES, V. "Nietzsche e Kant: em torno do niilismo" In: Cem anos após o projeto "vontade de poder - transmutação de todos os valores", p.78.
} 
instinto dos teólogos o tomou em proteção! - Uma ação imposta pelo instinto da vida tem no prazer a prova de que é uma ação justa: e esse niilista com vísceras cristã-dogmáticas entendeu o prazer como objeção... O que destrói mais rapidamente do que trabalhar, pensar, sentir sem necessidade interna, sem uma profunda escolha pessoal, sem prazer? como autômato do "dever"? É a própria receita da décadence, até mesmo do idiotismo... ${ }^{28}$.

Nesse fragmento, Nietzsche demonstra uma nítida aversão pelo imperativo categórico kantiano, o qual, conforme já destacado, se caracteriza pela premissa de que toda ação deve ser postulada como máxima universal para que se torne moralmente válida. Postulando o sujeito como fundamento incondicionado e critério para a própria racionalidade, a razão prática kantiana não fornece possibilidades axiológicas para a própria autocrítica do sujeito, desenvolvendo assim um sistema moral que contém uma espécie de auto-alienação como fundamento, no próprio postulado formal do imperativo categórico. Ora, a questão que logo desponta em nosso pensamento é esta: como uma ação pode vir a se tornar critério moral de avaliação universal? Se a singularidade é a marca de nossas ações, como é possível que elas então tenham que se adequar a essa regra heterônoma? Olivier Reboul salienta que

Em Kant, os valores devem à lei moral, e só a ela, sua validez universal. Nietzsche responde que um valor não pode ser universal: por um lado, este não existe senão como um meio para um fim: por outro, fins e valores dependem das condições da vida e variam com elas. Mas, não se pode fazer da vida enquanto tal um valor universal? Não, porque a vida adota formas opostas em função dos diferentes tipos, pelo que não pode fundar valores universais ${ }^{29}$.

É por tal motivo que, de certa maneira, podemos afirmar que Kant reproduz no seu imperativo categórico os mesmos princípios das morais religiosas normativas, que determinam a adequação da subjetividade humana a regras externas que adquirem o caráter de valores transcendentes, posto que supostamente ordenadas pela própria divindade. Todavia, Kant julga escapar dessa hierarquização moralista ao postular a existência de um principio autônomo em nossas ações, de maneira que, mesmo conduzidos pela necessidade de tornarmos nossa conduta um postulado de aplicabilidade universal, nos tornamos

\footnotetext{
${ }^{28}$ NIETZSCHE, F. O Anticristo, $§ 11$, p. 17.

${ }^{29}$ REBOUL, O. Nietzsche, crítico de Kant, p. 73.
} 
intrinsecamente livres. As críticas nietzschianas ao formalismo kantiano aparentemente beiram o pastiche, mas, horribile dictu, pensando conforme os critérios valorativos nietzschianos, não seria talvez a própria moral kantiana uma espécie de pastiche contra a vida? Nessas condições, Nietzsche apresenta a seguinte colocação:

De um exame de doutorado. - "Qual a tarefa de todo ensino superior?" Fazer do homem uma máquina. - "Qual o meio para isso?" - Ele tem que aprender a enfadar-se - "Como ele consegue isso?" - Mediante o conceito de dever. "Quem é seu modelo para isso?" - O filólogo: ele ensina a suar - "Quem é o homem perfeito?" - O funcionário público. "Que filosofia oferece a mais elevada fórmula para o funcionário público?” - A de Kant: o funcionário público como coisa-em-si, alçado a juiz do funcionário público como fenômeno. - (NIETZSCHE, F. Crepúsculos dos Ídolos, "Incursões de um extemporâneo", § 29, p. 80).

Observando a realidade prática, constatamos que mesmo o indivíduo que atue conforme a acepção vulgar do dever jamais consegue agir plenamente de maneira impessoal no exercício das suas funções, e essa impossibilidade não é sintoma de degradação moral, mas prova de que a existência humana é incompatível com postulados normativos que exigem o automatismo incondicional das disposições éticas do indivíduo. De acordo com Olivier Reboul,

A razão prática não é senão uma faculdade inventada para as necessidades da causa, com o fim de o homem que atua segundo seu coração, suas convicções, se persuada de que atua conforme a razão; assim, esta justifica as instituições mais irracionais ${ }^{30}$.

A recusa de Nietzsche ao primado kantiano do dever reside no fato de que agindo desse modo corremos o risco de nos tornarmos autômatos, pessoas desprovidas de qualquer afetividade e singularidade criadora em nossa conduta ética. Do momento em que temos que bem proceder apenas em cumprimento ao frio dever, perde-se justamente a força intrínseca que potencializa a riqueza das nossas ações e interações, a afetividade. Conforme esclarece Olivier Reboul,

O imperativo só é categórico porque ignora a sua origem. Em realidade, um imperativo está sempre condicionado pelo meio ou a tendência

\footnotetext{
${ }^{30}$ REBOUL, O. Nietzsche, critico de Kant, p. 62.
} 
dominante do indivíduo que o promulga. Assim, Kant se limitou a universalizar seu próprio instinto de obediência ${ }^{31}$.

Talvez por uma necessidade psicofisiológica de preservação de seu próprio bem-estar de consciência, Kant tenha proposto o imperativo categórico na ação moral, como forma de legitimar filosoficamente a sua própria necessidade instintiva de equilíbrio moral. No opúsculo "Sobre um suposto direito de mentir por amor à humanidade", texto no qual Kant replica as críticas de Benjamin Constant que este lhe fez pelo fato do filósofo de Konigsberg defender o pronunciamento absoluto da verdade, mesmo em circunstancias empíricas que poderiam motivar o prejuízo físico do sujeito que enunciasse uma proposição de verdade, encontramos a culminação da absurdidade do imperativo moral kantiano: caso um amigo se esconda em nosso lar vislumbrando a obtenção de abrigo contra a investida de um assassino, devemos, conforme postula Kant, no caso do facínora se dirigir para nosso domicílio indagando sobre a presença do amigo, informar ao criminoso que aquele se encontra de fato escondido em nossa residência. Para Kant,

Essa mentira praticada por bondade pode, porém, por um acaso (casus) ser passível de penalidade, de acordo com as leis civis; mas aquilo que apenas por acaso escapa à punição pode também ser julgado injustiça de acordo com as leis exteriores. Por exemplo, se impedires, por meio de uma mentira, um indivíduo que agora mesmo, tomado de fúria assassina, ia cometer um assassínio, és responsável quanto ao aspecto jurídico por todas as conseqüências que daí possam advir. Mas se te restringires à estrita verdade, a justiça pública em nada te pode atingir, por mais imprevistas que sejam as conseqüências. É por conseguinte possível que tu, depois de teres honestamente respondido "sim" à pergunta do assassino relativa à presença em tua casa da pessoa odiada perseguida por ele, esta tenha ido embora sem ser notada, não estando mais ao alcance do assassino, e o crime portanto não seja cometido: se porém tivesses mentido e dito que a pessoa perseguida não esteja em casa, e ela tivesse realmente saído (embora sem teres conhecimento disso), e depois o assassino a encontrasse fugindo e executasse sua ação, com razão poderias ser acusado de autor da morte dela. Pois se tivesses dito a verdade, tal como a conhecias, talvez o assassino, ao procurar seu inimigo na casa, fosse preso pelos vizinhos que acudissem, e o crime teria sido impedido. Por conseguinte, quem mente, por mais bondosa que possa ser sua intenção, deve responder pelas conseqüências de sua ação, mesmo diante do tribunal civil, e penitenciar-se dela, por mais imprevistas que possam ser essas conseqüências; porque a veracidade é um dever que deve ser

${ }^{31}$ REBOUL, O. Nietzsche, crítico de Kant, p. 63. 
considerado a base de todos os deveres a serem fundados sobre um contrato, e a lei desses deveres, desde que se lhe permita a menor exceção, torna-se vacilante e inútil. É portanto um sagrado mandamento da razão, que ordena incondicionalmente e não admite limitação, por qualquer espécie de conveniência, o seguinte: ser verídico (honesto) em todas as declarações ${ }^{32}$.

Mais uma vez, em nome de um formalismo moral que pode ser categorizado como estéril, Kant considera que a verdade deve ser dita incondicionalmente, mesmo que ela acabe por motivar um malefício imediato àquele que se digna a falar a verdade; nessas condições, a mentira representa a expressão de um indivíduo submetido ao efeito flutuante das inclinações. Considero que duas colocações de imediato poderiam ser feitas a partir desse problema: 1) um criminoso não se preocuparia em ter a educação de perguntar ao dono da casa se porventura o alvo de seu ódio mortal se encontra no domicílio; 2) se de fato nutrirmos amizade pelo fugitivo, nos empenharemos em defendê-lo da ação do assassino.

Ora, existem casos em que essa necessidade extrínseca de se dizer incondicionalmente a verdade pode comprometer uma causa afirmativa, então, como o ato de se dizer a verdade de forma cega pode ser considerado algo tão elevado na condição humana? Se a verdade fosse pronunciada incondicionalmente por toda a humanidade em suas vivências cotidianas, a vida civilizada se tornaria impossível e as instituições públicas se tornariam anárquicas, pois os âmbitos que menos seguem os dispositivos de veracidade são aqueles que mais postulam a sua pertença, a ação política e a dimensão jurídica. O apreço kantiano pela verdade, analisado profundamente, também se fundamenta em bases teológicas, mais precisamente, cristãs. Percebemos assim uma oposição axiológica do primado kantiano pela veracidade em relação ao pensamento nietzschiano, desmistificador da ideia de verdade tão apreciada pela tradição ocidental. Conforme destaca Nietzsche,

Enquanto o indivíduo, num estado natural das coisas, quer preservar-se contra outros indivíduos, ele geralmente se vale do intelecto apenas para a dissimulação: mas, por que o homem quer, ao mesmo tempo, existir socialmente e em rebanho, por necessidade e tédio, ele necessita de um acordo de paz e empenha-se então para que a mais cruel bellum omnium contra omnes ao menos desapareça de seu mundo. Esse acordo de paz traz consigo, porém, algo que parece ser o primeiro passo rumo à obtenção daquele misterioso impulso à verdade. Agora, fixa-se aquilo que, doravante, deve ser "verdade", quer dizer, descobre-se uma designação

\footnotetext{
${ }^{32}$ KANT, I. "Sobre um suposto direito de mentir por amor à humanidade" In: Textos Seletos, p. 74-75
} 
uniformemente válida e impositiva das coisas, sendo que a legislação da linguagem fornece também as primeiras leis da verdade: pois aparece, aqui, pela primeira vez, o contraste entre verdade e mentira; o mentiroso serve-se das designações válidas, as palavras, para fazer o imaginário surgir como efetivo; ele diz, por exemplo, "sou rico", quando para seu estado justamente "pobre" seria a designação mais acertada. Ele abusa das convenções consolidadas por meio de trocas arbitrárias ou inversões dos nomes, inclusive. Se faz isso de uma maneira individualista e ainda por cima nociva, então a sociedade não confiará mais nele e, com isso, tratará de excluí-lo. Nisso, os homens não evitam tanto ser ludibriados quanto lesados pelo engano. Mesmo nesse nível, o que eles odeiam fundamentalmente não é o engano, mas as conseqüências ruins, hostis, de certos gêneros de enganos. Num sentido semelhantemente limitado, o homem também quer apenas a verdade. Ele quer as conseqüências agradáveis da verdade, que conservam a vida; frente ao puro conhecimento sem conseqüências ele é indiferente, frente às verdades possivelmente prejudiciais e destruidoras ele se indispõe com hostilidade, inclusive. E mais até: como ficam aquelas convenções da linguagem? São talvez produtos do conhecimento, do sentido da verdade: as designações e as coisas se recobrem? Então a linguagem é a expressão adequada a todas as realidades? Apenas por esquecimento pode o homem alguma vez chegar a imaginar que detém uma verdade no grau ora mencionado ${ }^{33}$.

A relação entre o desejo de verdade e os imperativos morais decorre da necessidade metafísica do homem acreditar na existência de uma realidade imutável, livre do fluxo transformador do devir. Esse projeto metafísico de associação entre verdade e Ser, iniciado na filosofia ocidental por Parmênides, consolidado pelo platonismo, referendado teologicamente pela moral cristã, encontra na obra de Kant a sua culminação.

\section{Considerações críticas}

Nietzsche se posiciona axiologicamente como um grande crítico da doutrina kantiana do dever e do postulado da compaixão como virtude primordial em Schopenhauer, percebendo em ambas as perspectivas sintomas da decadência dos instintos. Todavia, podemos defender a hipótese temerária de que, segundo filosofia nietzschiana, o primado da compaixão é mais realista e condizente com o existir humano do que a abstração normativa do dever; dessa maneira, agir motivado pela compaixão é fisiologicamente mais saudável do que a partir da introjeção do imperativo do dever, fabulação improcedente que

\footnotetext{
${ }^{33}$ NIETZSCHE, F. Sobre Verdade e Mentira no sentido extra-moral, §1, p. 29-30.
} 
representa a incompreensão dos processos vitais da existência, considerada para além de toda esfera moral.

Haveria mais plausibilidade em uma moralidade fundamentada na compaixão, que é um sentimento, logo, expressão concreta da imanência, do que em uma moralidade que visa suprimir justamente qualquer relação com as particularidades da vida humana; com efeito, a teoria do dever em Kant revela-se absurda e impraticável na realidade prática, pois por mais que o indivíduo vislumbre atuar de maneira objetiva, neutra e impessoal no exercício da moralidade é, a rigor, impossível que tal intento se realize em uma dinâmica existencial regida pela flutuação dos afetos. A partir do momento em que o indivíduo decodifica as máximas prescritivas de uma ação moral a mesma adquire predicados subjetivos, particulares. Nessas condições, podemos afirmar que o formalismo do dever kantiano é razoavelmente bem fundamentado na teoria, mas na prática não encontra qualquer significação genuína; além disso, uma vez que o âmbito da ética pressupõe a ação prática do indivíduo em sua relação social, perde todo sentido a elaboração de uma doutrina do dever impossível de se realizar efetivamente.

Cabe ainda destacar que Nietzsche não compreendeu o âmago da questão schopenhaueriana da compaixão, que não pode ser de forma alguma confundida com a piedade: este é um sentimento aparentemente nobre, mas que no fundo mascara uma hierarquização depreciativa entre aquele que padece e a pessoa que se afeta pela percepção desse sofrimento. Ao invés de gerar nesta pessoa a potencialização de um afeto afirmativo, a piedade acaba por degenerar paulatinamente a sua própria vitalidade. Segundo essa perspectiva, a crítica de Nietzsche ao conceito de piedade é pertinente com os mecanismos favoráveis ao crescimento da vida nos seus diversos modos expressivos, pois que não é um sentimento tônico da capacidade de agir, mas o seu mórbido lenitivo. O próprio senso comum confunde continuamente o que vem a ser "piedade", "caridade" e "compaixão". A segunda virtude se encontra axiologicamente e eticamente mais próxima da terceira, sendo caracterizada por uma espécie de disposição generosa e beatífica em favor da instauração de um estado de bem-estar para outrem, desfavorecido pelas circunstâncias da vida. Já a compaixão pressupõe o desenvolvimento de uma compreensão ontológica da existência humana, pois que, para existir uma disposição compassiva, é necessário que o compadecente seja capaz de identificar no "objeto" da compaixão algo em comum, 
independentemente de todas as figurações extensivas, sendo assim uma espécie de experiência de alteridade. Essa é a sua grande diferença em relação ao sentimento de piedade, que é uma mera disposição inclinativa diante do sofrimento alheio, marcada por uma afetação triste, que deprime a capacidade ativa do indivíduo e, tanto pior, sem que ocorra a manifestação de um sentimento transfigurador tal como se manifesta na experiência da compaixão. Conforme essa perspectiva, a crítica de Nietzsche ao conceito de piedade é pertinente com os mecanismos favoráveis ao crescimento da vida nos seus diversos modos expressivos, pois que a piedade não é um sentimento tônico da capacidade de agir, mas o seu mórbido lenitivo ${ }^{34}$.

$\mathrm{Na}$ piedade, aquele que se apieda diante do sofredor não vivencia uma completa transformação no seu modo de ser, mas apenas uma disposição temporária de sofrer moralmente diante da dor alheia; por sua vez, na experiência da compaixão, o elemento condutor primordial desse processo é a compreensão da identidade entre as duas partes, mesmo que haja a diferença figurativa entre os indivíduos. Por conseguinte, é fácil alguém se apiedar diante do infortúnio de alguém, mas é muito raro um indivíduo se compadecer de outrem por identificar neste uma parcela ontológica de seu próprio ser. Dessa maneira, o indivíduo piedoso continua manifestando disposições egoístas em suas avaliações existenciais.

Nietzsche afirma categoricamente que "o Cristianismo é chamado de religião da compaixão"35. Talvez fosse mais conveniente denominá-la de "religião da piedade", pois tal sentimento é exigido dos seus fiéis como uma condição indispensável para a realização daquela que é considerada como a "verdadeira prática moral cristã", mas a existência de tal disposição piedosa não representa, conforme destacamos anteriormente, uma capacidade de vivenciar uma experiência de alteridade, tal como ocorre no processo da compaixão. Tanto pior, a noção de piedade cristã se presta a escamotear a fraqueza vital própria da aplicação de tal "virtude", favorecendo assim a manutenção do poder eclesiástico para a casta sacerdotal, a pretensamente detentora do caminho da salvação espiritual do fiel.

\footnotetext{
${ }^{34}$ Conforme argumenta Deleuze em Nietzsche e a Filosofia, p. 225: "A Piedade é o amor da vida, mas da vida, fraca, doente, reativa".

${ }^{35}$ NIETZSCHE, F. O Anticristo, § 7, p.14.
} 


\section{Referências}

CACCIOLA, Maria Lúcia Mello e Oliveira. Schopenhauer e a questão do dogmatismo. São Paulo: EDUSP, 1994.

CARDOSO, Renato César. A ideia de justiça em Schopenhauer. Belo Horizonte: Argumentum, 2008.

DEBONA, Vilmar. Schopenhauer e as formas da razão: o teórico, o prático e o ético-místico. São Paulo: Annablume, 2010.

DELEUZE, Gilles. Nietzsche e a filosofia. Trad. de António M. Magalhães. Porto: Rés-Editora, 2001.

KANT, Immanuel. Crítica da Razão Prática. Trad. de Valério Rohden. São Paulo: Martins Fontes, 2002.

2001. Fundamentação da Metafisica dos Costumes. Trad. de Paulo Quintela. Lisboa: Edições 70,

. "Sobre um suposto direito de mentir por amor à humanidade" In: Textos Seletos. Trad. de Floriano de Sousa Fernandes. Petrópolis: Vozes, 2009, p. 72-78.

JANAWAY, Christopher. Schopenhauer. Trad. de Adail Ubirajara Sobral. São Paulo: Loyola, 2003.

NIETZSCHE, Friedrich. O Anticristo / Ditirambos de Dionisio. Trad. de Paulo César de Souza. São Paulo: Companhia das Letras, 2006.

. Assim falava Zaratustra - um livro para todos e para ninguém. Trad. de Paulo Osório de Castro. Lisboa: Relógio d'água, 1998.

Crepúsculo dos Ídolos ou como se filosofa com o martelo. Trad. de Paulo César de Souza. Companhia das Letras: São Paulo: 2006.

Ecce Homo - como alguém se torna o que se é. Trad. de Paulo César de Souza. São Paulo: Companhia das Letras, 2001.

. Genealogia da Moral - Uma polêmica. Trad. de Paulo César de Souza. São Paulo: Companhia das Letras, 2000.

. Humano, demasiado humano - um livro para espíritos livres. Trad. de Paulo César de Souza. Rio de Janeiro: Companhia das Letras, 2003.

. O nascimento da Tragédia ou helenismo e pessimismo. Trad. de J. Guinsburg. São Paulo: Companhia das Letras, 1996.

. Sobre Verdade e Mentira no sentido extra-moral. Trad. Fernando de Moraes Barros. São Paulo: Hedra, 2007. 
. Terceira Consideração Intempestiva: Schopenhauer Educador. In: "Escritos sobre Educação”. Trad. de Noéli Correia de Melo Sobrinho. Rio de Janeiro: Loyola/PUC-Rio, 2003.

REBOUL, Olivier. Nietzsche, crítico de Kant. Trad. de Júlio Quesada e José Lasaga. Barcelona: Anthropos, 1993.

SCHOPENHAUER, Arthur. O Mundo como Vontade e como Representação. Trad. de Jair Barboza. São Paulo: EDUSP, 2005.

. Sobre o Fundamento da Moral. Trad. de Maria Lucia Mello e Oliveira Cacciola. São Paulo: Martins Fontes, 2001.

SOROMENHO-MARQUES, Viriato. "Nietzsche e Kant: em torno do Niilismo" In: António Marques (Org.) Cem anos após o projeto "vontade de poder - transmutação de todos os valores". Lisboa: Vega, 1989, p. 65-89.

TUGENDHAT, Ernst. "A Ética da Compaixão: animais, crianças, vida pré-natal” In: Lições sobre Ética. Trad. de A. Ruedell. Petrópolis: Vozes, 2000, p. 190-211.

Recebido: $18 / 06 / 11$

Received: 06/18/11

Aprovado: 10/07/11

Approved: 07/10/11 